\title{
Shoot Heterogeneity Effects on Shiraz/Richter 99 Grapevines. II. Physiological Activity
}

\author{
H. Cloete ${ }^{*}$, E. Archer ${ }^{2}$, V. Novello ${ }^{3}$ and J.J. Hunter ${ }^{4}$
}

(1) Department of Viticulture and Oenology, University of Stellenbosch, Stellenbosch 7600, South Africa; and CPUT, Private Bag X8, Wellington 7654, South Africa

(2) Lusan Premium Wines, PO Box 104, Stellenbosch 7599, South Africa

(3) Dipartimento di Colture Arboree, I 10095 Grugliasco TO, Italy

(4) ARC Infruitec-Nietvoorbij, Private Bag X5026, Stellenbosch 7599, South Africa; and Department of Viticulture and Oenology, University of Stellenbosch, Stellenbosch 7600, South Africa

Submitted for publication: July 2007

Accepted for publication: March 2008

Key words: Grapevine, shoot heterogeneity, physiology, shoot length

In this study, the physiology of normally developed and underdeveloped shoots is compared in an attempt to quantify the effect of shoot heterogeneity in a Shiraz/Richter 99 vineyard, located in the Stellenbosch area of the Western Cape, South Africa. Comparisons are made between normally developed and underdeveloped shoots from shaded and well-exposed canopies. In the first five weeks after véraison, photosynthetic and transpiration rates, stomatal conductance and water-use efficiency (WUE) decreased as berry ripening progressed, while the internal $\mathrm{CO}_{2}$ levels of the leaves increased. Since differences in activity between individual leaves from normally developed and underdeveloped shoots only became apparent in the third week after véraison, it seemed as if the leaf area per shoot played a more important role than the photosynthetic output per unit leaf area in determining photosynthetate supply to the rest of the vine up to this stage. From the third week after véraison, higher levels of photosynthetates were produced by normally developed shoots than by underdeveloped shoots, due to the larger effective leaf area per shoot as well as the higher photosynthetic activity per unit leaf area. This points to premature senescence of the leaves on underdeveloped shoots. The quantity and quality of the yield from normally developed shoots are expected to benefit from the higher physiological output of the leaves. The enhancing effect on leaf functioning induced by canopy exposure became apparent from the third week after véraison.

Yield, berry maturation and wine quality are dependent on canopy structure (Carbonneau, 1995). The leaf area (LA):trellis surface area (SA) ratio correlated well with must and wine analyses and sensory scores (Smart, 1982), as well as with the canopy microclimate (Smart et al., 1985). The physiological functioning of the canopy was found to be dependent on the amount and spatial distribution of the leaf surface (Archer \& Strauss, 1989a). According to Carbonneau et al. (1997) the exposed leaf area that is able to reach maximum photosynthetic rate, thus ensuring a largely positive carbon balance for the plant beyond its own carbon requirement, is a good estimation of the physiological potential of the whole canopy. This implies that the number of leaves on each individual shoot that are able to photosynthesise optimally may be a good estimation of the physiological potential of that specific shoot, and thus of the vine.

In order to reach the photosynthetic potential of a shoot (and vine), photosynthetic conditions, including sunlight exposure, should be optimal for each leaf (Hunter et al., 1991). Although genetic factors set an upper limit to photosynthetic capacity, observed instantaneous rates of photosynthesis are more commonly dictated by environmental conditions such as water supply, light, temperature, $\mathrm{CO}_{2}$ and $\mathrm{O}_{2}$, as well as by internal control mechanisms that affect the overall demand for photosynthetates and the partitioning of assimilates within the vine (Huglin, cited in Kriedemann, 1977).

The photosynthetic efficiency and sucrose export rate of leaves depend on the amount and intensity of sunlight interception (Hunter, 1991). The higher the number of leaves that are exposed to sunlight radiation and thus increased photosynthetic photon flux density (PPFD), the higher the rate of photosynthesis, until a limit is reached (Kriedemann, 1968). Optimal photosynthesis occurs at 704 to $1100 \mu \mathrm{mol} / \mathrm{m}^{2} / \mathrm{s}$ (Champagnol, 1984), while the light saturation point seems to differ between grape cultivars (Naor et al., 1994 and references therein). Due to excessive vegetative growth, dense canopies lead to a suboptimal canopy microclimate that is detrimental to the photosynthetic rate of the whole canopy (Hunter \& Visser, 1988; Hunter et al., 1991).

Radiation and temperature are related linearly (Smart, 1987). Radiation (be it intensity or duration) increases the temperature of the exposed leaves, which leads to an increase in photosynthetic activity. The optimum temperature for photosynthesis is generally regarded as $25^{\circ} \mathrm{C}$ to $30^{\circ} \mathrm{C}$ (Kriedemann, 1977; Alleweldt et al.,

*Corresponding author: e-mail: theronh@cput.ac.za

Acknowledgements: All research was conducted at the ARC Infruitec-Nietvoorbij, Stellenbosch, South Africa. The authors wish to thank the personnel of the viticulture and grapevine physiology laboratory of the ARC Infruitec-Nietvoorbij, Stellenbosch, for technical assistance. The authors also wish to thank Dr Kidd of the University of Stellenbosch, for the statistical analyses. 
1982). This optimum may vary under field conditions. According to Kriedemann (1977), vine leaves suffer more from desiccation than from high temperature per se. As long as the leaf is hydrated, temperatures of up to $48^{\circ} \mathrm{C}$ can be endured. Temperatures higher than the optimum for photosynthesis affect enzyme activity negatively due to instability of the enzymes and tissue desiccation (Kriedemann, 1977; Hunter, 1991).

The total leaf area:crop load ratio may change the demand on the leaves for the supply of carbohydrates and therefore may affect the photosynthetic rate of individual leaves (Petrie et al., 2000). Source limitation of photosynthesis occurs when the capacity of assimilate-supplying reactions is inadequate for the demand from the sink tissues (Iacono et al., 1995). In the grapevine, this is usually associated with a high reproductive:vegetative growth ratio when assimilate production of the leaf area is insufficient to meet the demand from the clusters (Bravdo \& Naor, 1995). Sink limitation, on the other hand, occurs when the rate at which assimilates are utilised and/or stored is lower than the rate at which such assimilates are produced and supplied to the sink tissues (Baysdorfer \& Bassham, cited in Iacono et al., 1995). This can be called under-cropping (Bravdo \& Naor, 1995). The result is an accumulation of photosynthetic end products in the leaves and an increase in the internal $\mathrm{CO}_{2}$ concentration, with a decrease in photosynthetic activity.

In this study, physiological parameters, particularly photosynthetic and related processes, were measured on field-grown vines in an attempt to quantify differences that may exist in the functioning of normally developed and underdeveloped shoots under well-exposed and shaded canopy conditions.

\section{MATERIALS AND METHODS}

\section{Vineyard}

A vineyard containing seven-year-old Vitis vinifera L. cv. Shiraz, clone SH1A, grafted onto Richter 99 (Vitis berlandieri x Vitis rupestris), clone RY2A, was used for this study. The vineyard is situated on the experimental farm of the Agricultural Research Council (ARC) Infruitec-Nietvoorbij near Stellenbosch in the Western Cape (Mediterranean climate). The vines are spaced $2.75 \mathrm{~m} \times 1.5 \mathrm{~m}$ on a Glenrosa soil with a western aspect $\left(26^{\circ}\right.$ slope) and trained onto a seven-wire lengthened Perold trellising system with movable canopy wires (VSP). Rows were orientated in a north-south direction.

Micro-sprinkler irrigation was applied at the pea-size berry and véraison stages. Pest and disease control was applied during the growth season according to the standard programme of the ARC.

\section{Experimental design}

The experiment comprised a completely randomised $2 \times 3 \times 2$ factorial design. The three factors were: degree of canopy exposure (well-exposed and shaded canopies); ripening stages (two, three and five weeks after véraison); and level of shoot development (normally developed and underdeveloped shoots). The 12 treatment combinations were each replicated three times.

Shaded and well-exposed canopies were randomly created in vines throughout the vineyard block. Only shoot positioning and topping were done to obtain shaded canopies, while additional suckering and leaf thinning (at berry set and pea-size berry in the basal half of the canopy/shoot) were applied where the vines were demarcated as well exposed. Normally developed and underdeveloped shoots were selected on the basis of their comparative length and level of lignification at veraison. The average length of normally developed shoots was $105 \mathrm{~cm}$ to $115 \mathrm{~cm}$, while the underdeveloped shoots were approximately $50 \mathrm{~cm}$ in length. The degree of lignification of the shoots was scored visually from one to five, with five being completely lignified and one being completely green (Cloete et al., 2006).

\section{Measurements}

The rate of photosynthesis $\left(\mu \mathrm{mol} / \mathrm{m}^{2} / \mathrm{s}\right)$, stomatal conductance $\left(\mathrm{mmol} / \mathrm{m}^{2} / \mathrm{s}\right)$, transpiration $\left(\mathrm{mmol} / \mathrm{m}^{2} / \mathrm{s}\right)$, PPFD $\left(\mu \mathrm{mol} / \mathrm{m}^{2} / \mathrm{s}\right)$, percentage relative humidity, internal $\mathrm{CO}_{2}$ ( $\mu$ bar) and leaf temperature $\left({ }^{\circ} \mathrm{C}\right)$ were measured in the vineyard with an ADC portable infrared gas analyser (The Analytical Development Co., England), as described by Hunter and Visser (1988). The water-use efficiency (WUE) was calculated by dividing the rate of photosynthesis by the transpiration rate.

Measurements were taken at 10:00 on the days scheduled (31 January, 8 February and 21 February 2002). Basally-situated (first three leaves above the clusters), sun-exposed leaves on the shoot were measured in all the cases. In order not to change leaf exposure to PPFD when the measurements were done, care was taken not to change the orientation of the leaves relative to the sun. Three leaves were measured per replicate.

\section{Statistical analyses}

Non-parametric bootstrap analyses were used when they proved to be more practical than factorial ANOVA. The significance of the results was evaluated using $95 \%$ confidence intervals. During the interpretation of the figures, differences were considered significant when no overlapping of the $95 \%$ confidence intervals occurred. Tendencies, rather than absolute statistically significant differences, were mostly discussed.

\section{RESULTS AND DISCUSSION}

\section{Effect of ripening stage on measured physiological parameters}

It seemed as if the photosynthetic rate of both normally developed and underdeveloped shoots, whether they occurred in shaded or exposed canopies, decreased between the second and fifth week after véraison (Fig. 1). The decreasing levels of PPFD (Fig. 2) in the basal parts of the canopies as grape ripening progressed after véraison could have affected the photosynthetic activity of the leaves. This decrease in radiation inside the canopies is in accordance with the findings of Hunter and Visser (1989), and has been attributed to normal shoot elongation by Marini and Marini (1983). Since no further increase in shoot length, leaf number or leaf area was found after véraison (Cloete et al., 2006), the decrease in PPFD could not have been due to self-shading in the canopies. As all the measurements were taken at the same time in the morning (10:00), the difference in the PPFD penetration at this time may have been due to a change in the angle of sunlight penetration into the canopies as the season progressed.

The observed decrease in photosynthetic rate also agrees with the work done by Kriedemann et al. (1970), who found a decline in photosynthesis after mature leaf size was reached. Since only basal leaves were measured in this experiment, all of them had attained their full mature size before veraison commenced (Cloete et al., 2006), partly explaining the observed decrease in photosynthetic rate. Leaf photosynthesis also seems to depend on the demand for assimilates (Hunter et al., 1991); an increase in the demand for photosynthetic products resulted in increased photosynthetic acti- 
vity. According to Kriedemann (1977), the demand for photosynthetate by sinks showed a downward trend as the season advanced. Hunter et al. (1994) also found that the photosynthetic activity of all the leaves, regardless of leaf position, decreased as the season progressed. The ageing of the leaves, together with sunlight conditions, most likely contributed to this. The decrease in photosynthesis resulted in higher average internal $\mathrm{CO}_{2}$ levels in the basal leaves of all the shoots in both canopy treatments (Fig. 3). This may indicate a decreased sink strength as grape ripening progressed. It also points to a decrease in assimilate transport, an accumulation of $\mathrm{CO}_{2}$ in the leaves, an increased resistance to $\mathrm{CO}_{2}$ assimilation, and therefore a reduction in the activity of the photosynthetic apparatus with an increase in leaf age (Kriedemann, 1977).

The ageing leaf anatomy and increasing internal resistance to $\mathrm{CO}_{2}$ transfer may also have affected stomatal conductivity and transpiration. In agreement with the findings of Hunter and Visser (1988) and Archer and Strauss (1989b), a decreasing tendency was found for these two parameters (Figs. $4 \& 5$ ). The decrease in stomatal conductance and transpiration rate may also partly be ascribed to a gradual increase in water stress. Irrigation was only applied two weeks before pea-size berry and one week after veraison during the course of this experiment. It was found that, as water stress developed in the vines due to soil water depletion, stomatal conductance decreased before any change in leaf water potential was detected (Flexas et al., 2000); this was due to the root signal (primarily abscisic acid) that regulates stomatal aperture under such conditions (Davies \& Zhang, 1991).

The WUE of the normally developed and underdeveloped shoots in shaded and exposed canopies decreased significantly in the fifth week after véraison (Fig. 6). Grimes and Williams (1990) and Williams et al. (1994) have shown than the WUE increases substantially with decreasing water supply. In this case, the decrease in WUE was probably due to the decrease in stomatal conductivity, since stomatal closure is the dominant factor changing WUE during a water deficit (Schultz, 1997). Since the final micro-irrigation was applied one week after véraison, it may be assumed that at least moderate water stress was experienced five weeks after véraison. However, it should be borne in mind that the water loss (rate of transpiration) was higher than what would have been expected from stomatal conductance, due to very high temperatures experienced five weeks after véraison. Despite the low stomatal conductivity, the high transpiration rate would have masked any possible increase in WUE due to stomatal closure. It therefore is possible that, if the measurements were taken on a cooler day in the same week, the WUE may have showed an increase, as suggested by the literature (Schultz, 1997).

\section{The effect of shoot development on measured physiological pa- rameters}

At two weeks after véraison, there was no significant difference in the physiological activity per unit leaf area between the normally developed and underdeveloped shoots. The rates of photosynthesis (Fig. 7) and transpiration (Fig. 8), stomatal conductance (Fig. 9) and internal $\mathrm{CO}_{2}$ levels (Fig. 10), as well as the WUE (Fig. 11), were similar. No external factor such as PPFD or leaf temperature seemed to limit leaf activity, while internal factors such as leaf age (Hunter \& Visser, 1988) and internal resistance to $\mathrm{CO}_{2}$ transfer (Kriedemann et al., 1970) did not seem to play a significant role at this stage.
Although no physiological difference was apparent between the shoot types, it must be borne in mind that the primary leaves of normally developed shoots were much larger than those of underdeveloped shoots (Cloete et al., 2006). Furthermore, a significantly higher number of secondary leaves with larger average areas were found on the normally developed shoots, resulting in a significantly higher total leaf area per shoot compared to underdeveloped shoots (Cloete et al., 2006). It therefore was assumed that the total production of carbohydrates was higher in the normally developed shoots than in the underdeveloped shoots in the second week after véraison.

From the third week after véraison, the difference between normally developed and underdeveloped shoots became more apparent. At three weeks after véraison, the rates of photosynthesis (Fig. 7) and transpiration (Fig. 8) and stomatal conductance (Fig. 9) in the normal shoots continued at levels similar to those measured in the previous week, while, in the underdeveloped shoots, these parameters decreased to levels significantly lower than those of the normal shoots.

Despite the constantly lower levels of PPFD received by the underdeveloped shoots, the average PPFD in the third week after véraison was higher than $1000 \mu \mathrm{mol} / \mathrm{m}^{2} / \mathrm{s}$ (Fig. 12). Since 704 to $1100 \mu \mathrm{mol} / \mathrm{m}^{2} / \mathrm{s}$ is considered to be optimum for the photosynthetic process (Champagnol, 1984), the level of PPFD was more than sufficient for maximal photosynthesis by the basal leaves from underdeveloped shoots and thus could not have been a reason for the significant decrease in stomatal conductance, transpiration and photosynthesis at this stage. However, a higher degree of variation was noted in the PPFD received by the basal leaves of underdeveloped shoots in both the shaded and exposed canopies. Although temperature, among others, is a critical external factor affecting photosynthesis (Kriedemann, 1977), no difference in leaf temperature was observed between normally developed and underdeveloped shoots in the third week after véraison (data not shown).

Since the earlier decrease in photosynthetic activity of the leaves from underdeveloped shoots compared to that of normal shoots could not be explained satisfactorily by external factors, such as sunlight radiation or leaf temperature, internal factors such as unbalanced vegetative:reproductive growth, leaf age and internal leaf structure were also considered. An imbalance between vegetative and reproductive growth (over-cropping) may have existed in the underdeveloped shoots, since the average total leaf area per gram of fresh berry mass was calculated as only 10 $\mathrm{cm}^{2}$, whereas it is generally accepted that 10 to $12 \mathrm{~cm}^{2}$ effective leaf area is required to ripen one gram of grapes (Hunter \& Visser, 1990, and references therein). According to Kriedemann (1977) and Hunter (1991), the photosynthetic activity of a leaf depends on the sink demand for assimilates, and thus the rate of photosynthesis of the leaves of the underdeveloped shoots was expected to increase as the demand for photosynthetates increased. This was, however, not realised in the underdeveloped shoots. Old leaves show a reduction in both photosynthetic capacity and efficiency, which is associated with an increase in internal resistance to $\mathrm{CO}_{2}$ assimilation (Kriedemann, 1977) There is, however, no reason to believe that the basal leaves of the underdeveloped shoots differed significantly in age to the leaves on the normally developed shoots. It is possible that the internal structure of the leaves from 


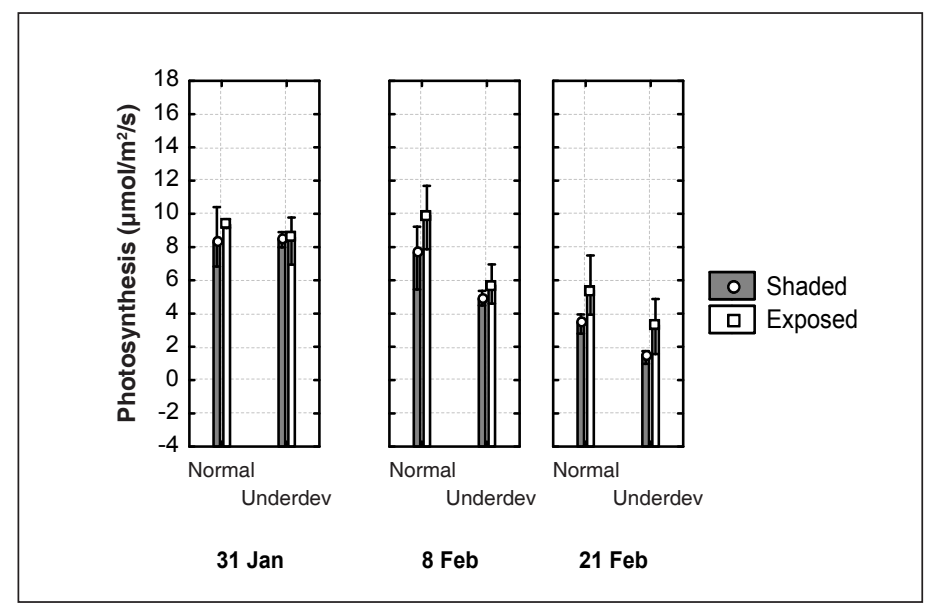

FIGURE 1

Photosynthetic rates of basal leaves from normally developed and underdeveloped shoots in shaded and well-exposed canopies measured in the second, third and fifth week after véraison. Error bars indicate 95\% confidence intervals (bootstrap analysis).

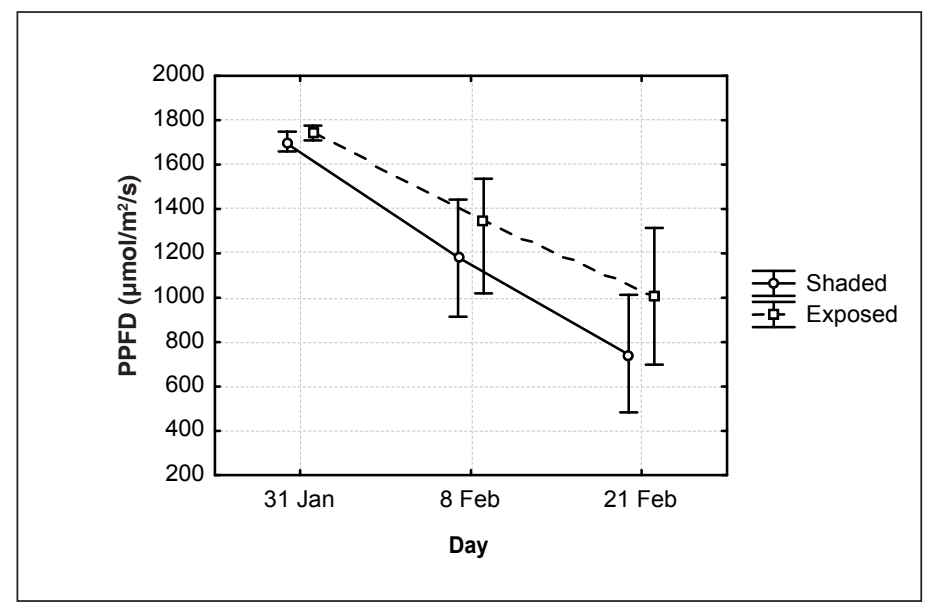

FIGURE 2

PPFD received by basal leaves in shaded and well-exposed canopies in the second, third and fifth week after véraison. Error bars indicate 95\% confidence intervals (bootstrap analysis).

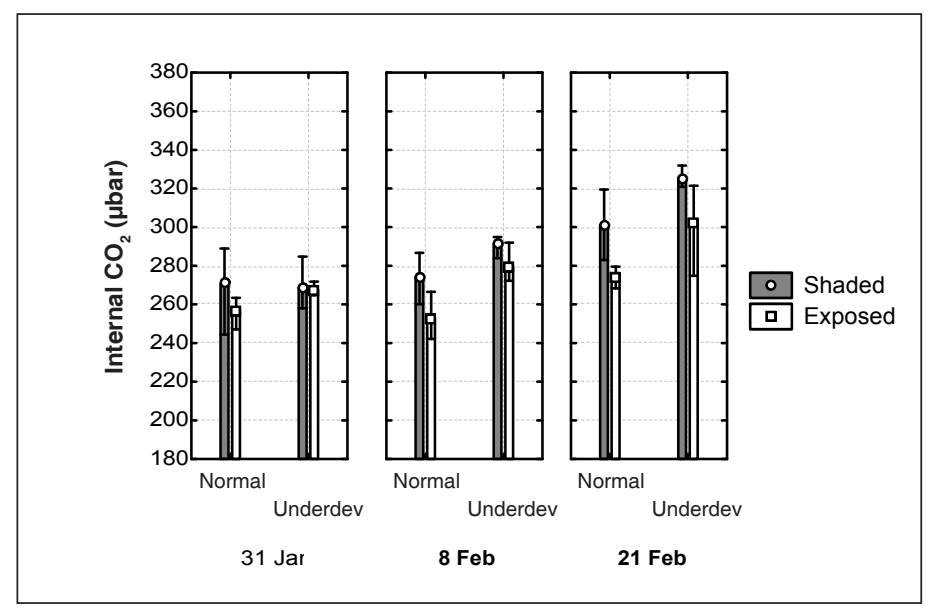

FIGURE 3

Internal $\mathrm{CO}_{2}$ of basal leaves from normally developed and underdeveloped shoots in shaded and well-exposed canopies measured in the second, third and fifth week after véraison. Error bars indicate $95 \%$ confidence intervals (bootstrap analysis).

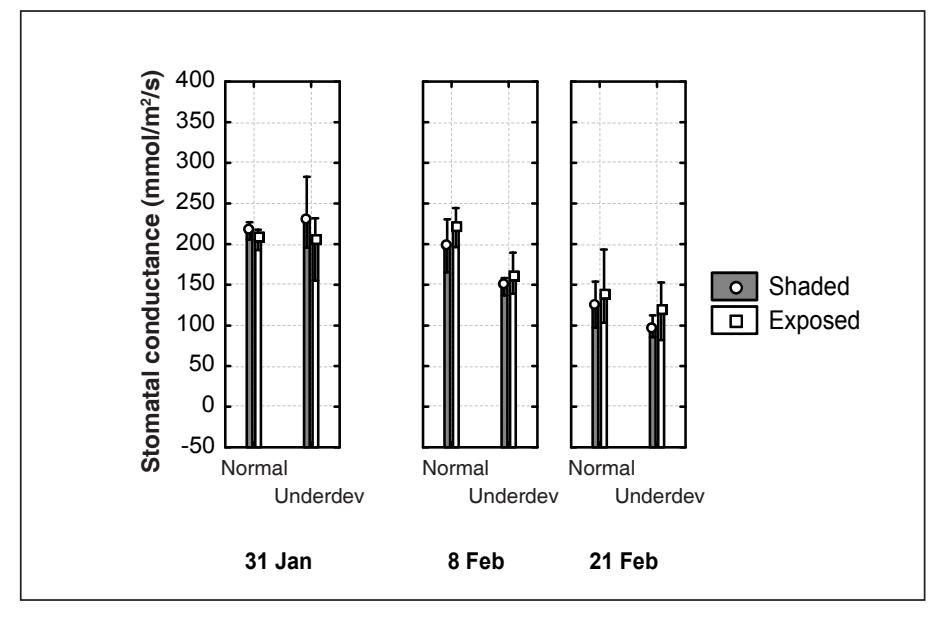

FIGURE 4

Stomatal conductance of basal leaves from normally developed and underdeveloped shoots in shaded and well-exposed canopies measured in the second, third and fifth week after véraison. Error bars indicate 95\% confidence intervals (bootstrap analysis).

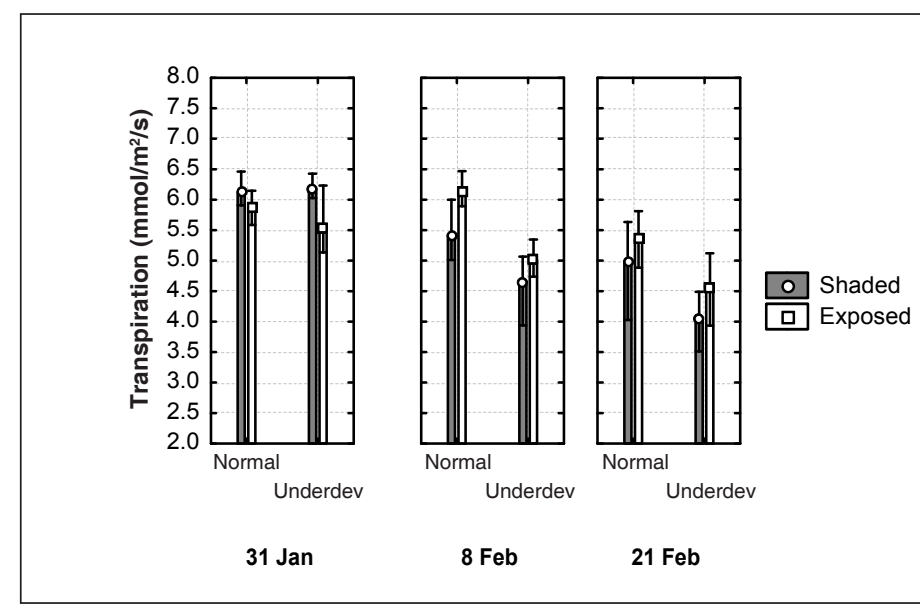

FIGURE 5

Transpiration rates of basal leaves from normally developed and underdeveloped shoots in shaded and exposed canopies measured in the second, third and fifth week after véraison. Error bars indicate 95\% confidence intervals (bootstrap analysis).

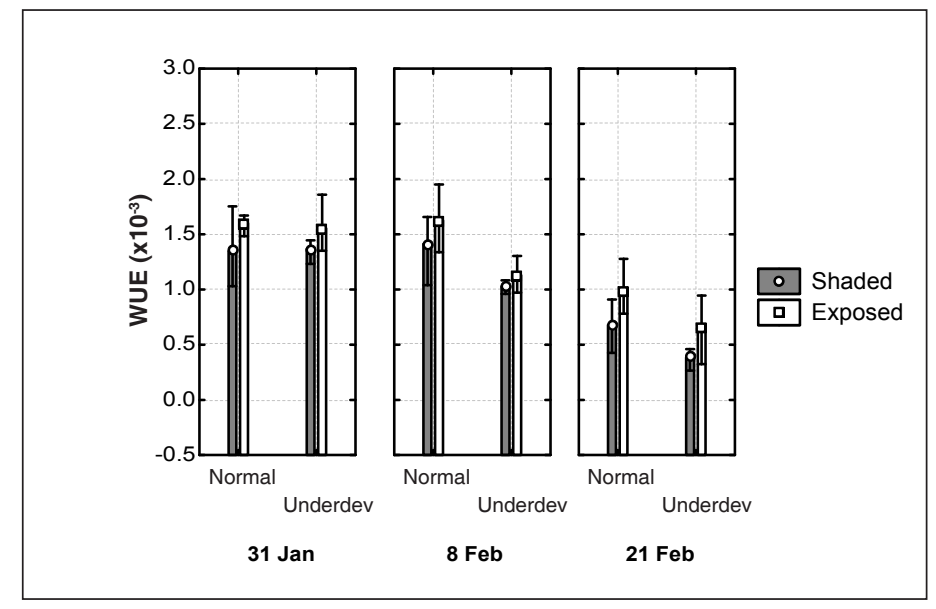

FIGURE 6

Water-use efficiency (WUE) of basal leaves from normally developed and underdeveloped shoots in shaded and well-exposed canopies measured in the second, third and fifth week after véraison. Error bars indicate 95\% confidence intervals (bootstrap analysis) 


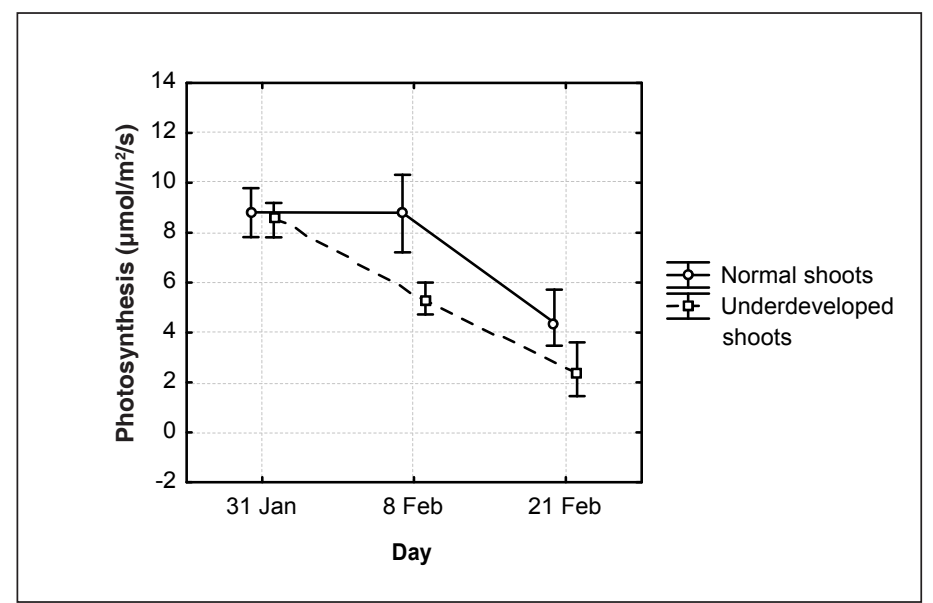

FIGURE 7

Photosynthetic rates of basal leaves from normally developed and underdeveloped shoots measured in the second, third and fifth week after véraison. Error bars indicate $95 \%$ confidence intervals (bootstrap analysis).

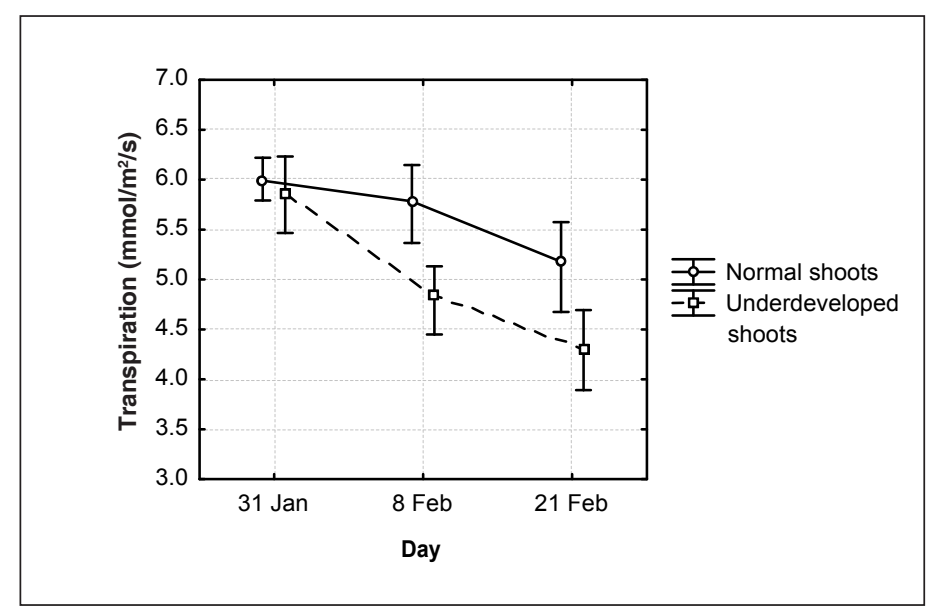

FIGURE 8

Transpiration rates of basal leaves from normally developed and underdeveloped shoots measured in the second, third and fifth week after véraison. Error bars indicate $95 \%$ confidence intervals (bootstrap analysis).

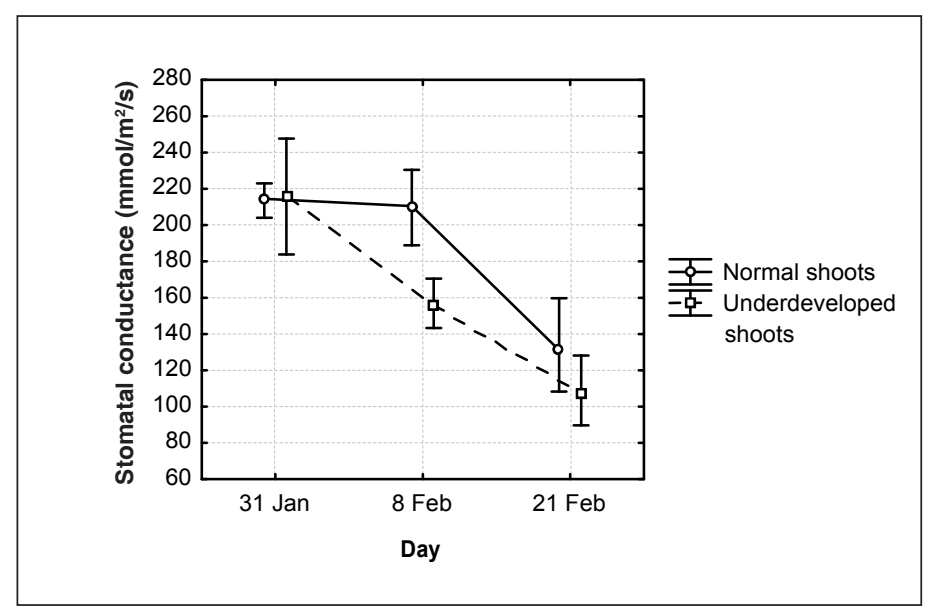

FIGURE 9

Stomatal conductance of basal leaves from normally developed and underdeveloped shoots measured in the second, third and fifth week after véraison. Error bars indicate $95 \%$ confidence intervals (bootstrap analysis).

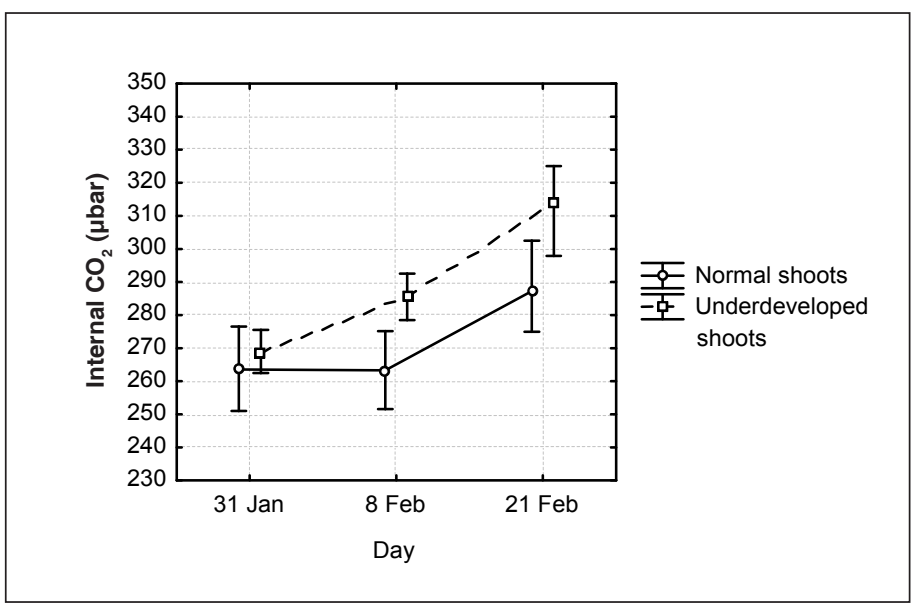

FIGURE 10

Internal $\mathrm{CO}_{2}$ of basal leaves from normally developed and underdeveloped shoots measured in the second, third and fifth week after véraison. Error bars indicate $95 \%$ confidence intervals (bootstrap analysis).

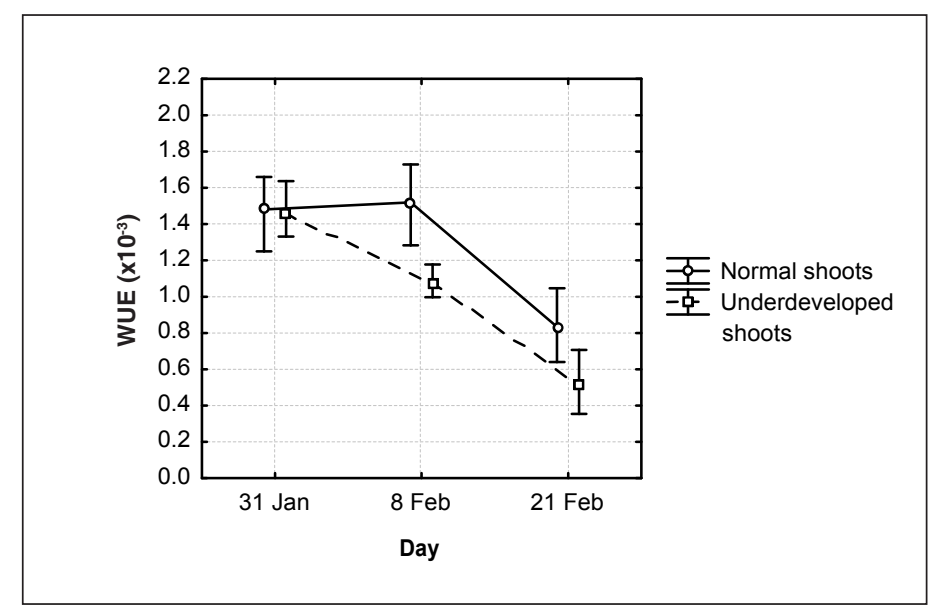

FIGURE 11

Water-use efficiency (WUE) of basal leaves from normally developed and underdeveloped shoots measured in the second, third and fifth week after véraison. Error bars indicate $95 \%$ confidence intervals (bootstrap analysis).

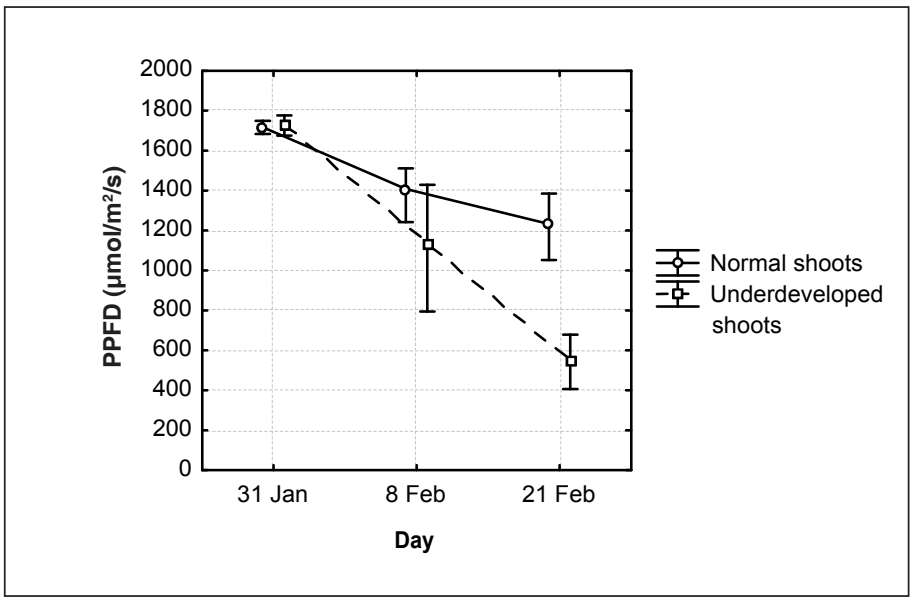

FIGURE 12

PPFD received by basal leaves of normally developed and underdeveloped shoots in the second, third and fifth week after véraison. Error bars indicate $95 \%$ confidence intervals (bootstrap analysis). 
the underdeveloped and normal shoots differed from each other, since Crookston et al. (1975) found increased mesophyll resistance in shade-grown bean leaves. As lower PPFD (albeit not statistically significant) was received by the underdeveloped compared to the normally shoots (Fig. 12), a similar mechanism may have been operative in the former, which may explain the decrease in photosynthetic rate. However, the leaves were not investigated anatomically. It is also possible that the internal structure of the leaves of the underdeveloped shoots was deteriorating slowly as the season progressed because of the high demand from the sinks, which left no room for reserve build-up, recovery or maintenance metabolism.

At five weeks after véraison, the measured parameters still indicated higher levels of physiological functioning in the normally developed than in the underdeveloped shoots. Since higher rates of photosynthesis per unit leaf area (Fig. 7), as well as a higher total leaf area per shoot (Fig. 13), were measured for the normally developed shoots than for the underdeveloped shoots, it was assumed that the total production (and thus export) of carbohydrates was higher in the normally developed shoots. It therefore is ex- pected that a higher yield of better quality may be obtained from normal than from underdeveloped shoots.

\section{Effect of canopy exposure on measured physiological parameters}

No significant differences between the canopies were found during the second week after véraison, although a marginally higher photosynthetic rate and lower transpiration rate were measured in the more exposed canopies (Table 1). Although factors such as the PPFD received and internal $\mathrm{CO}_{2}$ levels in the leaves could have affected photosynthesis and transpiration, no significant differences in these parameters were found between the shaded and well-exposed canopies (Table 1).

The advantageous effect of well-exposed canopies on the physiological activity of the leaves became more noticeable from the third week after véraison. Higher PPFD levels, rates of stomatal conductivity, transpiration and photosynthesis, as well as increased WUE, were measured in the exposed than in the shaded canopies (Tables $2 \& 3$ ). These findings are in agreement with those of Hunter and Visser (1988), who found an increase in sunlight penetration, an increase in photosynthetic and transpiration rates and

TABLE 1

Average values of specified physiological parameters in shaded and well-exposed canopies determined at two weeks after véraison in 2002.

\begin{tabular}{cccccc}
\hline & $\begin{array}{c}\text { PPFD } \\
\left(\mu \mathrm{mol} / \mathbf{m}^{2} / \mathbf{s}\right)\end{array}$ & $\begin{array}{c}\text { Stomatal } \\
\text { conductance } \\
\left(\mathbf{m m o l} / \mathbf{m}^{2} / \mathbf{s}\right)\end{array}$ & $\begin{array}{c}\text { Transpiration } \\
\left(\mathbf{m m o l} / \mathbf{m}^{2} / \mathbf{s}\right)\end{array}$ & $\begin{array}{c}\text { Photosynthesis } \\
\left(\boldsymbol{\mu m o l} / \mathbf{m}^{2} / \mathbf{s}\right)\end{array}$ & $\begin{array}{c}\text { Internal CO } \\
(\boldsymbol{\mu b a r})\end{array}$ \\
\hline Shaded & 1696 & 224.4 & 6.15 & 8.38 & 269.9 \\
Exposed & 1747 & 206.3 & 5.70 & 8.99 & 262.3 \\
\hline
\end{tabular}

None of the above parameters differed significantly between the shaded and well-exposed canopies on a $95 \%$ confidence level.

TABLE 2

Average values of specified physiological parameters in shaded and well-exposed canopies determined at three weeks after véraison in 2002.

\begin{tabular}{cccccc}
\hline & $\begin{array}{c}\text { PPFD } \\
\left(\mu \mathrm{mol} / \mathbf{m}^{2} / \mathbf{s}\right)\end{array}$ & $\begin{array}{c}\text { Stomatal } \\
\text { conductance } \\
\left(\mathbf{m m o l} / \mathbf{m}^{2} / \mathbf{s}\right)\end{array}$ & $\begin{array}{c}\text { Transpiration } \\
\left(\mathbf{m m o l} / \mathbf{m}^{2} / \mathbf{s}\right)\end{array}$ & $\begin{array}{c}\text { Photosynthesis } \\
\left(\mu \mathbf{m o l} / \mathbf{m}^{2} / \mathbf{s}\right)\end{array}$ & $\begin{array}{c}\text { Internal CO } \\
(\boldsymbol{\mu b a r})\end{array}$ \\
\hline Shaded & 1182 & 175.4 & 5.04 & 6.28 & 282.6 \\
$(\mathbf{x 1 0})$ & 1.24 & 7.82 & 266.3 \\
\hline
\end{tabular}

None of the above parameters differed significantly between the shaded and well-exposed canopies on a $95 \%$ confidence level.

TABLE 3

Average values of specified physiological parameters in shaded and well-exposed canopies determined at five weeks after véraison in 2002.

\begin{tabular}{|c|c|c|c|c|c|c|}
\hline & $\begin{array}{c}\text { PPFD } \\
\left(\mu \mathrm{mol} / \mathrm{m}^{2} / \mathrm{s}\right)\end{array}$ & $\begin{array}{c}\text { Stomatal } \\
\text { conductance } \\
\left(\mathrm{mmol} / \mathrm{m}^{2} / \mathrm{s}\right)\end{array}$ & $\begin{array}{c}\text { Transpiration } \\
\left(\mathbf{m m o l} / \mathbf{m}^{2} / \mathbf{s}\right)\end{array}$ & $\begin{array}{l}\text { Photosynthesis } \\
\left(\mu \mathrm{mol} / \mathrm{m}^{2} / \mathrm{s}\right)\end{array}$ & $\begin{array}{c}\text { Internal } \mathrm{CO}_{2} \\
(\mu \text { bar })\end{array}$ & $\begin{array}{l}\text { WUE } \\
\left(\times 10^{-3}\right)\end{array}$ \\
\hline Shaded & 755 & 110.7 & 4.51 & 2.49 & 313.0 & 0.55 \\
\hline Exposed & 1019 & 128.5 & 4.96 & 4.37 & 288.2 & 0.85 \\
\hline
\end{tabular}

None of the above parameters differed significantly between the shaded and well-exposed canopies on a $95 \%$ confidence level. 


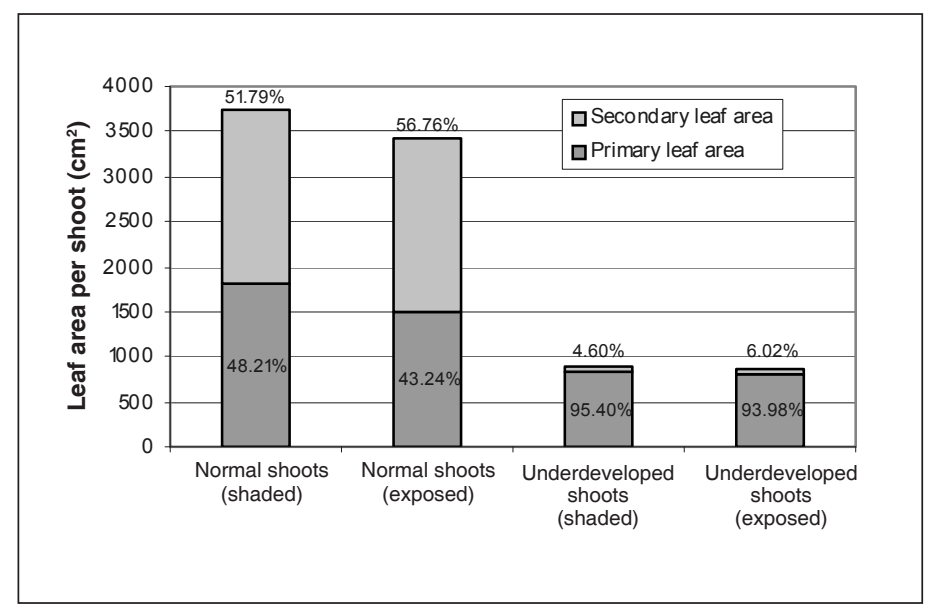

FIGURE 13

Average contribution of the primary and secondary leaves to the total leaf area per shoot (Cloete et al., 2006).

a decrease in stomatal resistance with increasing levels of canopy defoliation. Archer (1988) also states that, during optimal light conditions, leaves receiving direct sunlight are photosynthetically the most effective. The higher WUE calculated in the exposed canopies is in accordance with the findings of Hunter and Visser (1988), who have suggested that the utilisation of $\mathrm{CO}_{2}$ might be more effective in more exposed canopies. It seemed as if the shoot types were affected differently by the degree of canopy exposure, since the normally developed shoots constantly received higher levels of PPFD in the more exposed canopies throughout the first five weeks of berry ripening, while the underdeveloped shoots received similar exposure to sunlight in the shaded and the wellexposed canopies (Fig. 14).

It is clear that canopy management practices, and thus the creation of well-exposed canopies (which are strongly recommended in the majority of commercial vineyards), should be executed judiciously. The data on the physiological activity of different shoots illustrate the importance of uniform, normally developed shoots in grapevine canopies.

\section{CONCLUSIONS}

In the first five weeks after véraison, photosynthesis, transpiration, stomatal conductivity and WUE decreased as berry ripening progressed, while the internal $\mathrm{CO}_{2}$ levels in the leaves increased. This may be ascribed to an increase in leaf age of the basal leaves and consequent change in internal anatomy and functionality, a decreased demand for assimilates by the vine, a decrease in the PPFD received, and an increase in water deficit.

The difference in physiological activity between leaves from the normally developed and underdeveloped shoots became apparent in the third week after véraison. It was found that the physiological activity (photosynthetic and transpiration rates) of leaves on the normal shoots was significantly higher than that of leaves on the underdeveloped shoots, on a leaf area basis, in the third as well as the fifth week after véraison. Since the total leaf area per normal shoot was also significantly higher than that per underdeveloped shoot, it can be accepted that the total carbohydrate production in normal shoots would be significantly higher than in underdeveloped shoots.

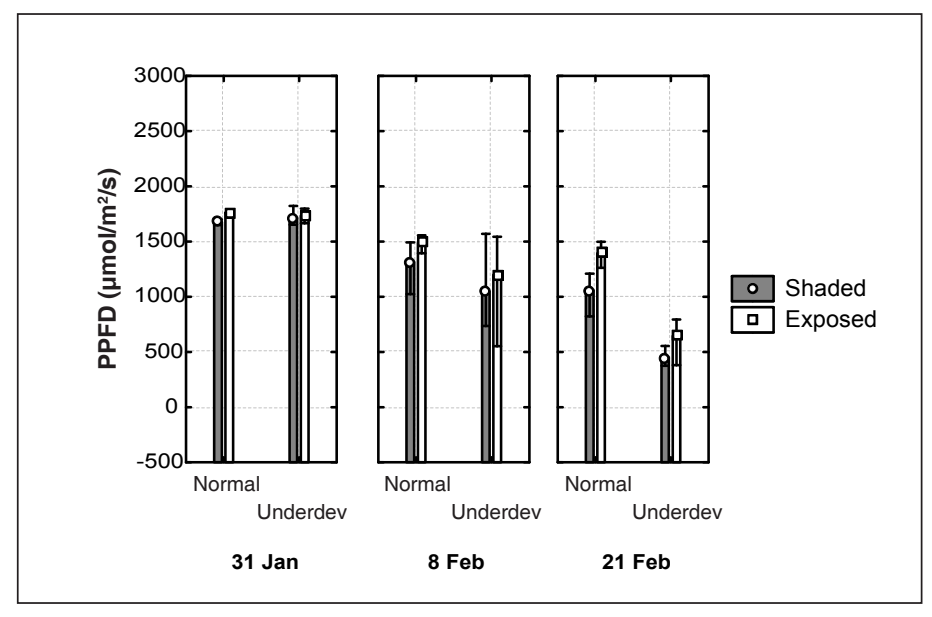

FIGURE 14

PPFD received by basal leaves of normally developed and underdeveloped shoots in shaded and well-exposed canopies in the second, third and fifth week after véraison. Error bars indicate $95 \%$ confidence intervals (bootstrap analysis).

The improving effect on physiological activity induced by better exposure of the canopies also became apparent from the third week after véraison. Although none of the differences were statistically significant, leaves in the well-exposed canopies received higher levels of PPFD and displayed higher rates of photosynthesis and transpiration, with lower stomatal resistance and lower internal $\mathrm{CO}_{2}$ levels. At five weeks after véraison, the photosynthetic rate of the leaves was significantly higher in the exposed than in the shaded canopies.

The results confirm that canopy management practices contribute to the improvement of leaf functioning in canopies that are less than ideal. The importance of a well-exposed canopy with homogeneous, normally developed shoots for promoting the physiological activity of the leaves and the potential for higher yields and grape quality is underlined.

\section{LITERATURE CITED}

Alleweldt, G., Eibach, R. \& Rühl, E., 1982. Investigations on gas exchange in grapevine. I. Influence of temperature, leaf age and daytime on net photosynthesis and transpiration. Vitis 21, 93-100.

Archer, E., 1988. Lighuishouding en somerloofbestuur in Suid-Afrikaanse wingerd. Wynboer, Januarie 1988, 3-5.

Archer, E. \& Strauss, H.C., 1989a. Invloed van oorskaduwing op die prestasie van Cabernet Sauvignon. Wynboer, September 1989, 10-11.

Archer, E. \& Strauss, H.C., 1989b. The effect of plant spacing on the water status of soil and grapevines. S. Afr. J. Enol. Vitic. 10, 49-58.

Bravdo, B. \& Naor, A., 1995. Effect of water regime on productivity and quality of fruit and wine. Acta Hort. 427, 15-26.

Carbonneau, A., 1995. General relationship within the whole-plant: examples of the influence of vigour status, crop load and canopy exposure on the sink "berry maturation" for the grapevine. Acta. Hort. 427, 99-118.

Carbonneau, A., Lebon, E., Mabrouk, H. \& Sinoquet, H., 1997. Interactions: canopy shape $\times$ vigour level: consequences on architecture and microclimate of the grapevine. Acta. Hort. 526, 91-105.

Champagnol, F., 1984. Photosynthèse. In: Elements de physiologie de la vigne et de viticulture generale. Dehan 34000, Montpellier, 40-66.

Cloete, H., Archer, E. \& Hunter, J.J., 2006. Shoot heterogeneity effects on Shiraz/ Richter 99 grapevines. I. Vegetative growth. S. Afr. J. Enol. Vitic. 27, 68-75.

Crookston, R.K., Treharne, K.J., Ludford, P. \& Ozbun, J.L., 1975. Response of beans to shading. Crop Science 15, 412-416. 
Davies, W.J. \& Zhang, J., 1991. Root signals and the regulation of growth and development of plants in drying soil. Annu. Rev. Plant Physiol. Plant Mol. Biol. $42,55-76$

Flexas, J., Bota, J., Escalona, J., Sampol, B. \& Medrano, H., 2000. Stomatal conductance as indicator of water stress in grapevines: Threshold between predominant stomatal and non-stomatal limitation to photosynthesis. 6th Int. Symp. on Grapevine Phys. and Biotech., Heraklion, Greece. p. 80.

Hunter, J.J., 1991. Die invloed van loofbestuur op druifkwaliteit. Short course in oenology, 27-28 August 1991, Nietvoorbij, Stellenbosch.

Hunter, J.J., De Villiers, O.T. \& Watts, J.E., 1991. The effect of partial defoliation on quality characteristics of Vitis vinifera L. cv. Cabernet Sauvignon grapes. I. Sugars, acids and pH. S. Afr. J. Enol. Vitic. 12, 42-50.

Hunter, J.J., Skrivan, R. \& Ruffner, H.P., 1994. Diurnal and seasonal physiological changes in leaves of Vitis vinifera L.: $\mathrm{CO}_{2}$ assimilation rates, sugar levels and sucrolytic enzyme activity. Vitis 33, 189-195.

Hunter, J.J. \& Visser, J.H., 1988. The effect of partial defoliation, leaf position and developmental stage of the vine on the photosynthetic activity of Vitis vinifera L. cv. Cabernet Sauvignon. S. Afr. J. Enol. Vitic. 9, 2, 9-15.

Hunter, J.J. \& Visser, J.H., 1989. The effect of partial defoliation, leaf position and developmental stage of the vine on leaf chlorophyll concentration in relation to the photosynthetic activity and light intensity in the canopy of Vitis vinifera L. cv. Cabernet Sauvignon. S. Afr. J. Enol. Vitic. 10, 67-73.

Hunter, J.J. \& Visser, J.H., 1990. The effect of partial defoliation on growth characteristics of Vitis vinifera L. cv. Cabernet Sauvignon. II. Reproductive growth. S. Afr. J. Enol. Vitic. 11, 26-32.

Iacono, F., Bertamini, M., Scienza, A. \& Coombe, B.G., 1995. Differential effects of canopy manipulation and shading of Vitis vinifera L. cv. Cabernet Sauvignon.
Leaf gas exchange, photosynthetic electron transport rate and sugar accumulation in berries. Vitis 34, 201-206.

Kriedemann, P.E., 1968. Photosynthesis in vine leaves as a function of light intensity, temperature, and leaf age. Vitis 7, 213-220.

Kriedemann, P.E., 1977. Vineleaf photosynthesis. Proc. Int. Symp. on the Qual. of the Vintage. Feb. 1977, Cape Town, South Africa. pp. 67 - 87.

Kriedemann, P.E., Kliewer, W.M. \& Harris, J.M., 1970. Leaf age and photosynthesis in Vitis vinifera L. Vitis 9, 97-104.

Marini, R.P. \& Marini, M.C., 1983. Seasonal changes in specific leaf weight, net photosynthesis, and chlorophyll content of peach leaves as affected by light penetration and canopy position. J. Amer. Soc. Hort. Sci. 108, 600-605.

Naor, A., Bravdo, B. \& Gelobter, J., 1994. Gas exchange and water relations in field-grown Sauvignon blanc grapevines. Am. J. Enol. Vitic. 45, 423-428.

Petrie, P.R., Trought, M.C.T., Howell, G.S., Palmer, J.W. \& Bucham, G.D., 2000. Whole grapevine carbon balance over a 24 hour period. 6th Int. Symp. on Grapevine Phys. and Biotech., Heraklion, Greece. p. 110.

Schultz, H.R., 1997. Physiological mechanisms of water use efficiency in grapevines under drought conditions. Acta. Hort. 526, 114-136.

Smart, R.E., 1982. Vine manipulation to improve wine grape quality. Proc. Grape and Wine Cent. Symp. Davis, California. pp. $362-375$.

Smart, R.E., 1987. Influence of light on composition and quality of grapes. Acta. Hort. 206, 37-47.

Smart, R.E., Robinson, J.B., Due, G.R. \& Brien, C.J., 1985. Canopy microclimate modification for the cultivar Shiraz I. Definition of canopy microclimate. Vitis $24,17-31$. 